\title{
GAMBARAN TINGKAT KEPUTUSASAAN PADA WANITA KORBAN KEKERASAN DALAM RUMAH TANGGA
}

\author{
Lia Hervika ${ }^{1}$, Monty P. Satiadarma², Naomi Soetikno ${ }^{3}$ \\ ${ }^{1}$ Fakultas Psikologi, Universitas Tarumanagara Jakarta \\ Email: lia.717191014@stu.untar.ac.id \\ ${ }^{2}$ Fakultas Psikologi, Universitas Tarumanagara Jakarta \\ Email: monty_satiadarma@yahoo.com \\ ${ }^{3}$ Fakultas Psikologi, Universitas Tarumanagara Jakarta \\ Email:naomis@fpsi.untar.ac.id
}

Masuk : 10-03-2021, revisi: 28-04-2021, diterima untuk diterbitkan : 29-05-2021

\begin{abstract}
ABSTRAK
Kekerasan dalam rumah tangga (KDRT) mendominasi kasus kekerasan terhadap perempuan (KTP) di Indonesia. Beberapa penelitian menunjukkan korban KDRT mengalami dampak psikologis, seperti depresi dan ide bunuh diri. Meskipun memberikan dampak yang negatif, masih terdapat wanita yang menerima dan membenarkan KDRT yang dilakukan oleh suami. Selain itu, banyak juga korban yang memilih untuk keluar dari siklus KDRT. Temuan tersebut menunjukkan respon wanita tampak berbeda terhadap pengalaman KDRT. Keputusasaan merupakan salah satu faktor yang diteliti pada wanita korban KDRT. Wanita korban KDRT yang putus asa cenderung mengalami kesulitan dalam mengambil keputusan, terutama keputusan untuk berpisah dari pelaku kekerasan dan keluar dari siklus kekerasan. Penelitian ini bertujuan mengetahui gambaran tingkat keputusasaan pada 52 wanita yang pernah mengalami kekerasan dalam rumah tangga di Indonesia. Metode penelitian bersifat kuantitatif deskriptif dan data dikumpulkan menggunakan kuesioner Beck Hopelessness Scale (BHS). Hasil menunjukkan 68\% partisipan penelitian memiliki keputusasaan pada kategori sedang. Partisipan yang tidak bekerja, berlatar pendidikan SMA/SMK, tidak atau belum memiliki anak, tidak melaporkan, dan tidak memiliki dukungan sosial cenderung memiliki skor keputusasaan yang lebih tinggi. Keterbatasan jumlah partisipan menyebabkan generalisasi hasil penelitian terbatas. Penelitian selanjutnya dapat mengkaji partisipan dengan cakupan wilayah dan latar belakang budaya yang lebih luas. Latar belakang budaya tentu menjadi salah satu faktor yang memengaruhi keputusasaan serta keputusan wanita yang mengalami KDRT untuk berpisah atau tetap berada pada siklus KDRT yang dialami.
\end{abstract}

Kata Kunci: Keputusasaan, Wanita, KDRT, Kekerasan terhadap Wanita, Kekerasan Dalam Rumah Tangga

\section{ABSTRACT}

Violence against women in Indonesia is dominated by domestic violence. During the pandemic situation, the victim may become hampered in reporting the case. Previous studies show that domestic violence might bring psychological impacts to the victim, like depression and suicidal ideation. Hopelessness might affect the response among victims. Previous studies reported that women who experienced domestic violence had moderate to high levels of hopelessness. They tend to show poor decision-making and hard to break the violence cycle. This study aims to describe the level of hopelessness in 51 women who have experienced domestic violence in Indonesia. The research method is descriptive quantitative. Data were collected using Beck Hopelessness Scale (BHS). Results showed $68 \%$ of participants have moderate level of hopelessness. Participants with no occupation, high school educational background, not reporting the case, and do not have social support tend to have higher score of hopelessness. This study provides information about levels of hopelessness but the generalization of the result is limited due to the limited participants and cultural background. Further research should describe more number of participants with wider cultural background.

Keywords: Hopelessness, Women, Domestic Violence, Violence against women

\section{PENDAHULUAN}

\section{Latar Belakang}

Jumlah kasus kekerasan terhadap perempuan di Indonesia mengalami peningkatan pada tahun 2019, yaitu tercatat 14.719 kasus berdasarkan data yang diperoleh dari Komisi Nasional Anti Kekerasan Terhadap Perempuan (2020). Pada beragam jenis kasus kekerasan terhadap perempuan, kasus Kekerasan Dalam Rumah Tangga (KDRT) merupakan kasus yang paling 
banyak terjadi dengan persentase $75 \%$. Kasus KDRT adalah kekerasan atau perilaku agresi yang menyebabkan penderitaan secara fisik, psikologis, dan seksual, termasuk juga penelantaran dan manipulasi yang terjadi pada lingkungan rumah tangga. Penelitian ini akan membahas KDRT yang dilakukan oleh suami terhadap istri.

Di Indonesia, KDRT masih merupakan masalah yang dianggap tabu, aib, dan memalukan bagi korban yang mengalami. Namun, terdapat juga kelompok yang menerima dan membenarkan KDRT yang dilakukan suami terhadap istri. Pandangan tersebut didasarkan pada pemahaman dan keyakinan bahwa suami berhak melakukan kekerasan dalam memimpin rumah tangga. Respon wanita terhadap KDRT beragam (Fajrini et al., 2018, Deborah et al., 2018, Karakurt et al., 2014). Terdapat wanita yang memilih untuk berpisah dengan pelaku kekerasan sehingga memilih untuk tetap bersama pelaku dan berada dalam siklus kekerasan. Namun, terdapat juga wanita yang memilih untuk berpisah dan keluar dari siklus kekerasan yang dialami (Kisa et al., 2018).

Penelitian yang dilakukan oleh Kisa et al., (2018) menunjukkan bahwa wanita yang mengalami kekerasan cenderung memiliki tingkat keputusasaan yang tinggi dan sulit untuk mengambil keputusan. Sebaliknya, wanita yang memilih untuk berpisah dan memiliki rencana bekerja dan berkarir cenderung memiliki keputusasaan rendah. Keputusasaan adalah harapan negatif terhadap diri sendiri dan masa depan. Individu yang putus asa cenderung kehilangan motivasi, memiliki afeksi dan harapan yang negatif terhadap masa depan. Mereka memiliki persepsi bahwa tidak ada yang dapat dilakukan untuk membuat hidup menjadi lebih baik dibandingkan saat ini. Keputusasaan pada wanita yang mengalami KDRT juga dapat menjadi faktor yang memengaruhi pengambilan keputusan untuk berpisah atau tetap berada pada siklus kekerasan yang dialami.

Berdasarkan paparan mengenai keputusasaan pada wanita yang mengalami KDRT, dapat diketahui bahwa keputusasaan merupakan salah satu faktor yang menentukan keputusan korban dalam meresponi KDRT. Oleh sebab itu, penelitian ini bertujuan untuk menggambarkan tingkat keputusasaan pada wanita yang mengalami KDRT di Indonesia. Hasil penelitian ini diharapkan dapat menjadi penelitian referensi bagi penelitian selanjutnya yang akan mengkaji topik KDRT lebih mendalam terutama pada kaum wanita di Indonesia.

\section{Rumusan Masalah}

Penelitian-penelitian terdahulu menunjukkan perbedaan respon pada wanita yang mengalami Kekerasan Dalam Rumah Tangga. Salah satu faktor yang menarik perhatian adalah tingkat keputusasaan yang berperan dalam pengambilan keputusan pada wanita korban KDRT (Kisa et al., 2018). Oleh sebab itu, penelitian ini merumuskan masalah yaitu bagaimana gambaran tingkat keputusasaan pada wanita yang mengalami KDRT?

\section{METODE PENELITIAN}

\section{Partisipan}

Terkumpul 94 data yang mengisi kuesioner penelitian. Data melewati proses skrining untuk memastikan bahwa data yang diolah bersifat valid. Data yang valid yaitu data yang diisi secara lengkap dan partisipan memiliki pengalaman KDRT yang terdiri dari (1) kekerasan fisik (dipukul, ditampar, diseret, disakiti secara fisik, tindakan menyebabkan luka dan penderitaan secara fisik), (2) kekerasan psikologis (ancaman, hinaan, kekerasan secara verbal, tindakan yang menyebabkan tekanan secara mental), (3) kekerasan seksual (pemaksaan hubungan seksual, tindakan fisik yang dilakukan tanpa kesepakatan kedua belah pihak), dan (4) penelantaran dan 
manipulasi secara ekonomi (penelantaran dan tidak memberikan nafkah, dihambat atau dibiarkan tanpa pemenuhan kehidupan yang layak). Sejumlah 43 data dianggap tidak valid karena partisipan tidak memiliki pengalaman KDRT. Partisipan penelitian terdiri dari 51 wanita yang pernah atau sedang mengalami Kekerasan Dalam Rumah Tangga (KDRT) yang dilakukan oleh suami. Partisipan berada pada rentang usia 20-60 tahun, 75\% diantaranya bekerja, 57\% diantaranya sudah berpisah dengan pelaku KDRT, dan $15 \%$ diantaranya masih berada pada siklus KDRT.

\section{Pengukuran}

Pengukuran tingkat keputusasaan pada partisipan menggunakan kuesioner Beck Hopelessness Scale (BHS) yang dikembangkan oleh Beck et al. (1974) dan diterjemahkan ke dalam Bahasa Indonesia. Kuesioner BHS diuji coba dan menghasilkan 15 butir dengan reliabilitas koefisien Cronbach's alpha $\alpha=0.720$. Salah satu contoh butir kuesioner adalah 'Mungkin sebaiknya saya menyerah karena saya tidak bisa melakukan apapun untuk membuat kondisi saya lebih baik'. Partisipan menjawab dengan pilihan jawaban ' $1=$ Setuju' atau ' $0=$ Tidak Setuju'. Semakin tinggi total skor partisipan menunjukkan semakin tinggi tingkat keputusasaan pada partisipan.

\section{Rancangan dan Prosedur Penelitian}

Penelitian ini adalah penelitian non-eksperimental kuantitatif untuk mengetahui gambaran tingkat keputusasaan pada partisipan wanita yang mengalami Kekerasan Dalam Rumah Tangga (KDRT). Peneliti mengumpulkan literatur terkait dengan topik penelitian kemudian menentukan instrumen pengukuran yang akan digunakan. Setelah itu, instrumen alat ukur diuji coba pada kelompok wanita menikah. Setelah uji coba instrumen, pengambilan data penelitian dilakukan pada kelompok wanita yang sedang atau pernah mengalami KDRT. Data yang terkumpul disaring untuk memastikan partisipan memenuhi kriteria. Data yang valid diolah menggunakan software SPSS v.21. Pengelompokkan kategori tinggi, sedang, dan rendah ditentukan menggunakan pengelompokkan rerata partisipan dengan perhitungan $\mathrm{M} \pm \mathrm{SD}$.

\section{HASIL DAN PEMBAHASAN}

Hasil menunjukkan tingkat keputusasaan partisipan penelitian sebagai berikut. Secara keseluruhan, 35 orang atau $68 \%$ dari keseluruhan partisipan memiliki tingkat keputusasaan sedang. Partisipan dengan keputusasaan tinggi berjumlah 6 orang atau 12\%. Sementara itu, 10 orang atau $20 \%$ partisipan memiliki tingkat keputusasaan rendah.

Berdasarkan karakteristik status pekerjaan, partisipan yang tidak bekerja memiliki skor keputusasaan yang lebih tinggi dibandingkan partisipan yang bekerja, meskipun sama-sama berada pada kategori sedang. Hasil tersebut sejalan dengan Kisa et al. (2018) yang mengungkapkan wanita yang mengalami KDRT dan memiliki pekerjaan serta perencanaan karir cenderung memiliki tingkat keputusasaan yang lebih rendah.

Berdasarkan tingkat pendidikan, wanita dengan latar pendidikan SMA tampak memiliki skor keputusasaan tertinggi dibandingkan kelompok pendidikan lainnya. Sementara, wanitadengan latar belakang pendidikan S1 memiliki skor keputusasaan paling rendah. Hasil ini dapat dijelaskan dari Fajrini et al. (2018) yang mengungkapkan bahwa pengetahuan dan pemahaman mengenai KDRT juga menjadi faktor yang menentukan respon wanita terhadap pengalaman KDRT. Oleh sebab itu, edukasi mengenai kekerasan, khususnya KDRT dapat menjadi salah satu pengetahuan yang dapat disosialisasikan melalui kegiatan pendidikan formal. 
Berdasarkan jumlah anak, partisipan yang tidak atau belum memiliki anak cenderung memiliki skor keputusasaan tertinggi bila dibandingkan partisipan yang memiliki 1 anak dan 2 anak atau lebih meskipun masih berada pada kategori sedang.

Berdasarkan tindakan pelaporan terhadap pihak berwenang, partisipan yang melaporkan pengalaman KDRT memiliki keputusasaan yang rendah dibandingkan partisipan yang memilih untuk tidak melaporkan KDRT kepada pihak berwenang.

Berdasarkan ketersediaan dukungan sosial terhadap partisipan, mereka yang merasa tidak memiliki dukungan sosial menunjukkan keputusasaan yang lebih tinggi dibandingkan partisipan yang merasa memiliki dukungan sosial meskipun masih berada dalam kategori sedang. Hal tersebut sejalan dengan temuan dari Clark dan Finkel (2005) yang mengungkapkan kesempatan untuk mengekspresikan diri dan mendapatkan dukungan sosial dari kerabat dapat memberikan manfaat yang positif bagi wanita yang mengalami KDRT.

Tabel 1. Gambaran tingkat keputusasaan berdasarkan karakteristik partisipan

\begin{tabular}{|c|c|c|c|}
\hline Karakteristik partisipan & Skor & Kategori & Jumlah \\
\hline \multirow[t]{3}{*}{ Keseluruhan } & $<0.05$ & Rendah & 10 \\
\hline & $0.05-0.28$ & Sedang & 35 \\
\hline & $>0.28$ & Tinggi & 6 \\
\hline \multicolumn{4}{|l|}{ Kelompok usia } \\
\hline 20-40 tahun & 0.14 & Sedang & 44 \\
\hline $40-60$ tahun & 0.15 & Sedang & 7 \\
\hline \multicolumn{4}{|l|}{ Status Pekerjaan } \\
\hline Tidak Bekerja & 0.20 & Sedang & 13 \\
\hline Bekerja & 012 & Sedang & 38 \\
\hline \multicolumn{4}{|l|}{ Status Pernikahan } \\
\hline Menikah & 0.13 & Sedang & 21 \\
\hline Cerai Hidup & 0.15 & Sedang & 30 \\
\hline \multicolumn{4}{|l|}{ Pendidikan } \\
\hline $\mathrm{SD}$ & 0.14 & Sedang & 9 \\
\hline SMP & 0.10 & Sedang & 8 \\
\hline SMA/SMK & 0.22 & Sedang & 16 \\
\hline $\mathrm{S} 1$ & 0.04 & Rendah & 12 \\
\hline S2 dan seterusnya & 0.14 & Sedang & 6 \\
\hline \multicolumn{4}{|l|}{ Jumlah anak } \\
\hline 0 & 0.17 & Sedang & 14 \\
\hline 1 & 0.15 & Sedang & 22 \\
\hline 2 atau lebih & 0.09 & Sedang & 15 \\
\hline \multicolumn{4}{|c|}{ Pelaporan terhadap pihak berwenang } \\
\hline Melaporkan & 0.05 & Rendah & 11 \\
\hline Tidak melaporkan & 0.16 & Sedang & 40 \\
\hline \multicolumn{4}{|c|}{ Dukungan sosial (keluarga, teman) } \\
\hline Ada & 0.11 & Sedang & 35 \\
\hline Tidak ada & 0.20 & Sedang & 16 \\
\hline
\end{tabular}

Hasil menunjukkan partisipan mengalami beragam jenis kekerasan dalam rumah tangga (KDRT). Terdapat partisipan yang mengalami satu jenis kekerasan dan juga terdapat partisipanyang mengalami lebih dari satu jenis kekerasan. Terdapat satu partisipan yang memiliki persepsi mengalami empat jenis kekerasan, baik secara fisik, psikis, seksual, dan ekonomi. 31 partisipan melaporkan mengalami kekerasan fisik, sementara itu kekerasan seksual yang paling sedikit dialami oleh partisipan. Uraian data jenis kekerasan yang dialami oleh partisipan dapat dilihat pada Tabel 2. 
Tabel 2. Jenis kekerasan yang dialami oleh partisipan

\begin{tabular}{lc}
\hline \multicolumn{1}{c}{ Jenis Kekerasan } & Jumlah \\
\hline Fisik & 11 \\
\hline Psikis & 12 \\
\hline Ekonomi & 3 \\
\hline Seksual & 0 \\
\hline Fisik \& Psikis & 7 \\
\hline Fisik \& Ekonomi & 4 \\
\hline Psikis \& Ekonomi & 1 \\
\hline Psikis \& Seksual & 3 \\
\hline Fisik, Psikis, \& Seksual & 6 \\
\hline Fisik, Psikis, \& Ekonomi & 2 \\
\hline Psikis, Seksual, \& Ekonomi & 1 \\
\hline Fisik, Psikis, Seksual, \& Ekonomi & 1 \\
\hline Total & 51 \\
\hline
\end{tabular}

\section{KESIMPULAN DAN SARAN}

Berdasarkan penjabaran hasil penelitian di atas dapat disimpulkan bahwa sebagian besar partisipan berada pada kategori keputusasaan sedang. Wanita yang mengalami KDRT yang tidak bekerja, berlatar pendidikan SMA/SMK, tidak atau belum memiliki anak, tidak melaporkan, dan tidak memiliki dukungan sosial cenderung memiliki skor keputusasaan yang lebih tinggi. Sementara itu, partisipan yang berlatar belakang pendidikan S1 dan memilih untuk melaporkan pengalaman KDRT memiliki skor keputusasaan yang lebih rendah. Selain itu, jenis kekerasan yang dialami partisipan penelitian didominasi oleh kekerasan fisik dan psikis.

Keputusasaan merupakan variabel yang masih sedikit dikaji pada wanita korban KDRT sehingga penelitian ini memberikan kontribusi berupa gambaran tingkat keputusasaan pada wanita yang mengalami KDRT serta karakteristik partisipan. Sebagian besar dari partisipan tidak melaporkan pengalaman KDRT kepada pihak berwenang. Hal tersebut menunjukkan bahwa masih banyak kasus KDRT yang mungkin belum tercatat oleh pihak Komnas Anti Kekerasan terhadap Perempuan.

Faktor yang memengaruhi keputusan wanita untuk melaporkan KDRT yang dialami adalah keterbatasan akses dan atau tekanan dari lingkungan yang masih menganggap KDRT sebagai tabu dan aib. Faktor latar belakang budaya belum dibahas dalam penelitian ini sehingga menjadi keterbatasan penelitian dalam menggeneralisasi hasil penelitian terutama untuk penduduk Indonesia dengan beragam latar belakang budaya. Oleh sebab itu, faktor ragam latar belakang budaya dapat menjadi pertimbangan bagi peneliti selanjutnya yang akan meneliti topik yang berkaitan.

\section{Ucapan Terima Kasih (Acknowledgement)}

Ucapan terima kasih kepada para segenap partisipan dan rekan yang bersedia membantu menginfokan dan mendukung pelaksanaan penelitian dan pengambilan data. Ucapan terima kasih juga kepada Fakultas Psikologi Universitas Tarumanagara atas dukungan dalam pelaksanaan penelitian.

\section{REFERENSI}

Beck, A. T., Weissman, A., Lester, D. \& Trexler, L. (1974). The measurement of pessimism: The hopelessness scale. Journal of Consulting and Clinical Psychology, 42(6), 861-865. 
Clark, M. \& Finkel, E. J. (2005). Willingness to express emotion: The impact of relationship type, communal orientation, and their interaction. Personal Relationships 12(2), 169-180. doi: 10.1111/j.1350-4126.2005.00109.x

Deborah, S., Muthmainnah, A., Herlinda, L., \& Tanawi, S. S. (2018). Trauma dan resiliensi pada wanita penyintas kekerasan dalam rumah tangga. Jurnal Ilmiah Psikologi MANASA, 7(2), 121-130.

Fajrini, F., Ariasih, R. A., \& Latifah, N. A. (2018). Determinan sikap terhadap kekerasan dalam rumah tangga di Provinsi Banten. Aspirasi: Jurnal Masalah-Masalah Sosial, 9(2), 173189. Doi: https://doi.org/10.22212/aspirasi.v7i1.1084

Karakurt, G., Smith, D. \& Whiting, J. (2014). Impact of intimate partner violence on women's mental health. J Fam Violence, 29(7),693-702. Doi: 10.1007/s10896-014-9633-2

Kisa, S., Zeyneloglu, S. \& Verim, E. S. (2018). The level of hopelessness and psychological distress among abused women in a women's shelter in Turkey. Archives of Psychiatric Nursing, 33(1), 30-36. Doi: https://doi.org/10.1016/j.apnu.2018.08.009

Komisi Nasional Anti Kekerasan Tehadap Perempuan. (2020). Kekerasan meningkat: Kebijakan penghapusan kekerasan seksual untuk membangun ruang aman bagi perempuan dan anak perempuan. Catatan Tahunan Tentang Kekerasan terhadap perempuan tahun 2019 